\title{
STUDI PERENCANAAN DESAIN TURAP BAJA DENGAN METODE FINITE ELEMENT DI BANTARAN SUNGAI JELARAI TANJUNG SELOR
}

\author{
Yasinta Yati Nur Anbya ${ }^{1}$, Eko Andi Suryo ${ }^{2}$, As'ad Munawir ${ }^{3}$
}

\begin{abstract}
ABSTRAK
Bencana alam merupakan suatu kejadian yang diakibatkan oleh alam dan diperburuk oleh kurangnya perhatian dari manusia yang menghuni di bumi tentang kesadaran akan bencana, khususnya di Indonesia. Bencana alam pertama yang paling sering terjadi di Indonesia adalah banjir dan disusul oleh tanah longsor. Geoteknik merupakan dasar dari ilmu pengetahuan tentang tanah dan segala macam seluk beluk tanah beserta sifat sifat mekanik dan fisik dari tanah tersebut. Dengan diterapkannya geoteknik secara luas di masyarakat Indonesia, pastinya akan mengurangi dampak yang diakibatkan oleh tanah longsor yang merupakan salah satu bencana paling sering terjadi di Indonesia.Kegagalan struktur sheet pile di bantaran sungai sering kali terjadi karena lemahnya lapisan erosi yang melindungi struktur sheet pile tersebut. Semakin vertikal posisi sebuah struktur penahan tanah, harus dicatat bahwa arus sungai akan semakin tinggi dan mengerosi kaki bantaran sungai semakin cepat pula. Penelitian kali ini dilaksanakan karena bantaran sungai Jelarai Kabupaten Bulungan Kalimantan Utara mengalami kegagalan sheet pile, sehingga diperlukan perbaikan menyeluruh sepanjang bantaran sungai tersebut. Profil tanah yang didapatkan dari intrepetasi data CPT menyatakan bahwa rata-rata tanah di bantaran sungai Jelarai adalah pasir dan pasir berlanau dengan lapisan pasir berlanau sekitar 5-10m dari permukaan tanah dilanjutkan dengan pasir. Ditambah dengan arus sungai yang setiap hari pasang surut dengan kecepatan yang tinggi, maka kaki bantaran sungai menjadi mudah tererosi. Dalam desain perkuatan sheet pile terdahulu, bantaran sungai hanya diperkuat dengan sheet pile dan tidak dilindungi oleh lapisan kontrol erosi, sehingga tanah pasir yang dominan pada bantaran sungai Jelarai lebih mudah tergerus arus sungai. Dalam penelitian kali ini pula dibahas perencanaan struktur sheet pile yang memenuhi syarat kekuatan (strength) dan berkelanjutan (sustainable). Untuk syarat kekuatan, diperlukan kontrol faktor keamanan, perpindahan tanah, lendutan sheet pile, tegangan tanah rata-rata, dan momen lentur sheet pile. Sedangkan untuk syarat berkelanjutan diperlukan kontrol penanaman vegetasi dan penggunaan material-material yang ramah lingkungan. Perbaikan bantaran yang direncanakan meliputi pemasangan sheet pile, pemasangan lapisan kontrol erosi yaitu riprap, dan penanaman tanaman yang sesuai dengan komoditi yang mudah ditemukan di Kabupaten Bulungan. Pada penelitian kali ini, perangkat lunak yang digunakan adalah Plaxis yang terkenal sebagai perangkat lunak yang mampu memberikan output visual yang mudah sehingga analisa selanjutnya bisa terlaksana dengan mudah pula. Dalam beberapa literatur terdahulu tentang analisa stabilitas sheet pile, kebanyakan analisa hanya menggunakan cara perhitungan manual sehingga membutuhkan waktu yang lama untuk trial-error metode-metode yang telah lama dipergunakan untuk analisa stabilitas sheet pile. Sehungga dengan dipergunakannya dua perangkat lunak terbaru kali ini akan mendapatkan hasil analisa yang akurat.
\end{abstract}

Kata kunci : Intrepetasi CPT, Sheet pile, FEM, Plaxis, Riprap.

\footnotetext{
${ }^{1}$ Mahasiswa Pasca Sarjana Teknik Sipil Universitas Brawijaya MalangJL MT Haryono 167 Malang 65145 Jawa Timuryashintaanbya@ymail.com

${ }^{2}$ Dosen Teknik Sipil Universitas Brawijaya MalangJL MT Haryono 167 Malang 65145 Jawa Timur

${ }^{3}$ Dosen Teknik Sipil Universitas Brawijaya Malang JL MT Haryono 167 Malang 65145 Jawa Timur
} 


\section{PENDAHULUAN}

Perkuatan bantaran sungai merupakan struktur yang dapat berakibat fatal apabila terjadi kegagalan, terutama apabila banyak bangunan perumahan yang terletak diatas bantaran sungai tersebut. Ditambah dengan arus sungai yang tidak menentu setiap harinya, dan run off air hujan yang tinggi dari daratan yang menambah nilai kadar air tanah menyebabkan kaki bantaran sungai menjadi mudah tergerus dan struktur sheet pile menjadi turun dan hancur.

Penelitian yang telah dilaksanakan oleh Aneem Kumar (2014) tentang kegagalan yang paling berpengaruh terhadap kegagalan struktur sheet pile adalah perubahan kadar air tanah yang tiba-tiba dan masif. Kumar juga menjelaskan bagaimana faktor keamanan mempengaruhi kegagalan struktur sheet pile menggunakan program Plaxis ${ }^{\mathrm{TM}}$. Dalam penelitian kali ini, bantaran sungai Jelarai yang akan diperbaiki memiliki kesamaan sifat dengan penelitian Kumar, yaitu sungai yang pasang dan surut dalam waktu yang singkat dalam arus yang besar.

Dengan kata lain keruntuhan yang diakibatkan oleh stabilitas sheet pile yaitu meningkatnya tegangan geser suatu massa tanah atau menurunnya kekuatan geser suatu massa tanah. Dengan tujuan utama dari perencanaan sheet pile ini adalah memberikan alternatif desain atau perbaikan terhadap desain yang sudah ada. Maka serangkaian analisa stabilitas sheet pile menghasilkan data mekanisme keruntuhan yang mungkin akan terjadi di kemudian hari dengan beban yang semakin bertambah setiap tahunnya. Pemakaian perangkat lunak yang terbaru untuk menganalisa stabilitas sheet pile dengan dimensi sheet pile yang beragam diharapkan dapat memberikan gambaran pola keruntuhan bahkan angka keamanan yang beragam pula.

Dalam beberapa literatur terdahulu tentang analisa stabilitas sheet pile, kebanyakan analisa hanya menggunakan cara perhitungan manual sehingga membutuhkan waktu yang lama untuk trial-error metode-metode yang telah lama dipergunakan untuk analisa stabilitas sheet pile. Sehingga dengan dipergunakannya dua perangkat lunak terbaru kali ini akan mendapatkan hasil analisa yang akurat.

Parameter tanah yang dimasukkan dalam program Plaxis adalah hasil intrepetasi data CPT yang ditafsirkan menggunakan metode dari Robertson dan Lunne (1990). Parameter tanah yang diintrepetasikan berdasarkan nilai Qc dan Fr lalu dimasukkan kedalam grafik logaritmik jenis tanah yang telah diteliti oleh Robertson. Selain parameter tanah, parameter lain yang digunakan adalah parameter sifat sheet pile dan grouting beton yang dikutip dari sifat baja dan beton yang sudah banyak dipasaran.

\section{METODOLOGI}

Data sondir yang telah didapatkan lalu diplot kedalam grafik yang telah dikembangkan oleh Robertson(1997) yang dinamakan Soil Behavior Type Diagram seperti ditunjukkan pada Gambar 2.1Perlu konversi dari Qc $\left(\mathrm{kg} / \mathrm{cm}^{2}\right)$ menjadi Qc (bar) sebelum proses input data dimulai.

Setelah jenis tanah sudah didapatkan, maka langkah selanjutnya adalah proses pencocokan jenis tanah menjadi parameter tanah tipikal yang telah dikembangkan oleh USCS. Berikut parameter yang dibutuhkan untuk proses input program Plaxis ${ }^{\mathrm{TM}}$ adalah sudut geser tanah $\phi$, kohesi c, berat jenis tanah $\gamma$, modulus elastisitas E, dan koefisien permeabilitas tanah k. Setelah semua parameter tanah didapatkan, maka proses input data geometri dan parameter tanah sudah bisa dilaksanakan dalam program Plaxis TM. 


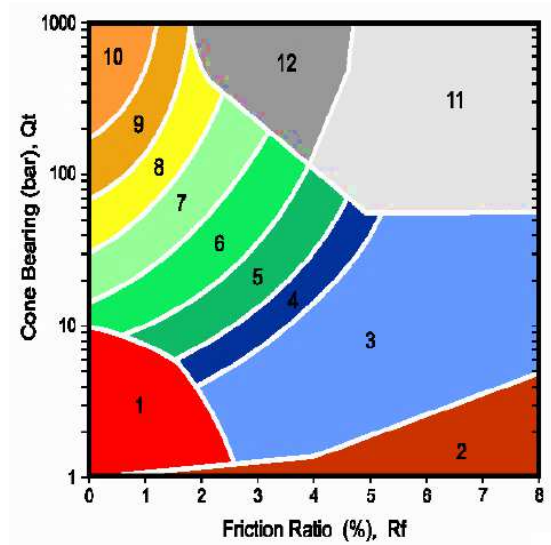

Gambar 2.1 Soil Behavior Type (Robertson (1997))

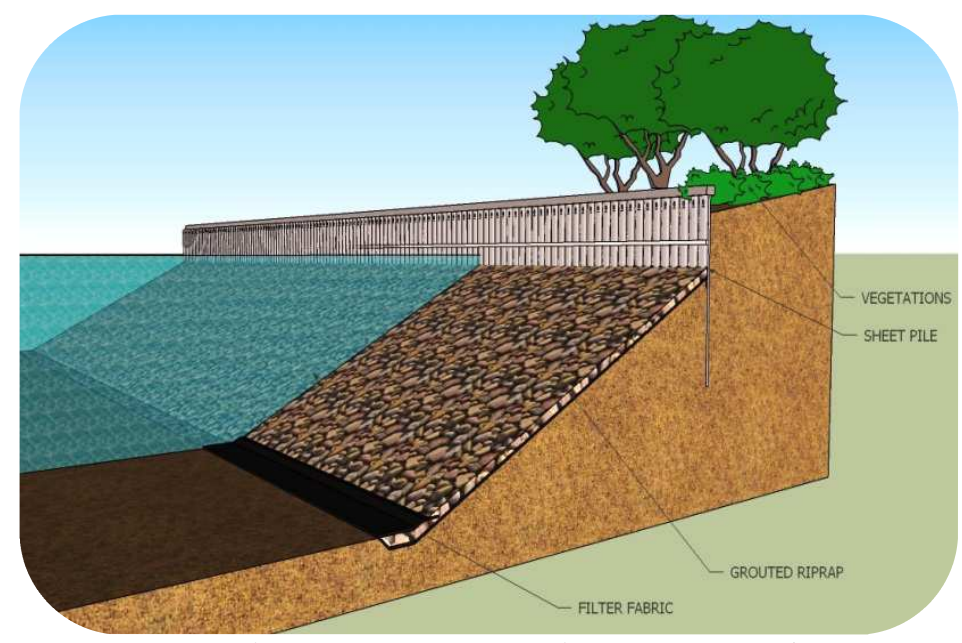

Gambar 2.2Perencanaan bantaran sungai

\section{HASIL DAN PEMBAHASAN}

\subsection{Analisis Jenis Tanah}

Penentuan parameter tanah yang akan dimasukkan kedalam progam Plaxis berasal dari intrepetasi data CPT yang telah dilakukan di Tanjung Selor. Karena keterbatasan data, maka metode Robertson (1990) yang dapat diaplikasikan untuk menentukan parameter tanah tipikal yang sesuai dengan data CPT.

Berdasarkan potongan keenam bantaran sungai yang telah ada, titik sondir yang terdekat adalah titik sondir 1, titik sondir 4, dan titik sondir 5. Dari ketiga data sondir tersebut, yang menjadi kunci intrepetasi data adalah Fr (Friction Ratio) dan Qc (kuat geser CPT). Berdasarkan Robertson (1990) pembagian jenis tanah adalah menjadi 10 jenis.

Namun karena hasil perhitungan Qc di lapangan memiliki satuan $\mathrm{kg} / \mathrm{cm} 2$ maka diperlukan konversi menjadi bar terlebih dahulu agar bisa diintrepetasikan sesuai diagram milik Robertson (1990) dengan mengalikan nilai Qc awal dengan 0,98. Metode Robertson (1990) dipilih karena mudah dalam pengaplikasiannya dan tidak membutuhkan perhitungan yang rumit untuk mendapatkan jenis tanah. 
Maka penentuan tanah tipikal dari table USCS adalah tahap selanjutnya dalam menentukan nilai parameter tanah. Berikut hasil penentuan nilai parameter tanah sesuai dengan nilai tipikal USCS dan dijelaskan didalamTabel 3.1.

Tabel 3.1Parameter tanah untuk titik 1

\begin{tabular}{|c|c|c|c|c|c|c|c|c|c|c|c|c|c|c|c|c|c|}
\hline \multicolumn{6}{|c|}{ POINT 1} & \multicolumn{6}{|c|}{ POINT 4} & \multicolumn{6}{|c|}{ POINT 5} \\
\hline \multirow{2}{*}{ 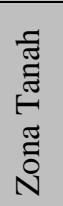 } & \multicolumn{2}{|c|}{$\gamma\left(\mathrm{kN} / \mathrm{m}^{3}\right)$} & \multirow{2}{*}{$\underbrace{\stackrel{\overbrace{}}{Z}}_{0}$} & \multirow[b]{2}{*}{ 豸్ఠ } & \multirow{2}{*}{ 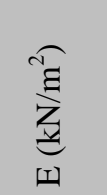 } & \multirow{2}{*}{ 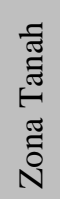 } & \multicolumn{2}{|c|}{$\gamma\left(\mathrm{kN} / \mathrm{m}^{3}\right)$} & \multirow{2}{*}{$\underbrace{\stackrel{\overbrace =}{z}}_{0}$} & \multirow[b]{2}{*}{$\stackrel{\varrho}{\sigma}$} & \multirow{2}{*}{ 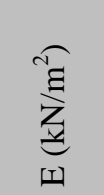 } & \multirow{2}{*}{ 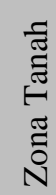 } & \multicolumn{2}{|c|}{$\gamma\left(\mathrm{kN} / \mathrm{m}^{3}\right)$} & \multirow{2}{*}{$\underset{0}{\stackrel{\text { Eg}}{Z}}$} & \multirow[b]{2}{*}{$\stackrel{\overbrace{}}{\vartheta}$} & \multirow{2}{*}{ 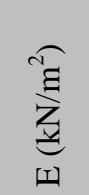 } \\
\hline & 咅 & 䔍 & & & & & 焉 & 密 & & & & & 穿 & 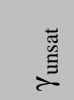 & & & \\
\hline 1 & 17,5 & 15 & 5 & 27 & 2500 & 1 & 17,5 & 15 & 5 & 27 & 2500 & 1 & 17,5 & 15 & 5 & 27 & 2500 \\
\hline 2 & 12,5 & 10 & 10 & 5 & 500 & 2 & 12,5 & 10 & 10 & 5 & 500 & 2 & 12,5 & 10 & 10 & 5 & 500 \\
\hline 5 & 18 & 15.5 & 18 & 25 & 6000 & 3 & 15 & 17.5 & 15 & 23 & 2000 & 3 & 15 & 17.5 & 15 & 23 & 2000 \\
\hline 6 & 18 & 15.5 & 19 & 31 & 9000 & 6 & 18 & 15.5 & 19 & 31 & 9000 & 6 & 18 & 15.5 & 19 & 31 & 9000 \\
\hline 7 & 18,5 & 16 & 20 & 33,5 & 12000 & 7 & 18,5 & 16 & 20 & 33,5 & 12000 & 7 & 18,5 & 16 & 20 & 33,5 & 12000 \\
\hline 8 & 19 & 16.5 & 22 & 34 & 16000 & 8 & 19 & 16.5 & 22 & 34 & 16000 & 8 & 19 & 16.5 & 22 & 34 & 16000 \\
\hline 9 & 19,5 & 17 & 0 & 37,5 & 40000 & 9 & 19,5 & 17 & 0 & 37,5 & 40000 & 9 & 19,5 & 17 & 0 & 37,5 & 40000 \\
\hline
\end{tabular}

Proses input dimulai dengan memasukkan nama material, model material, dan jenis material. Warna material dapat dipilih dengan memilih kotak warna yang berada di sisi kiri bawah, yang saat ini warna yang dipilih adalah merah untuk memudahkan identifikasi jenis tanah. Setelah input material selesai dilaksanakan, maka tahapan selanjutnya adalah memasangkan material kedalam model yang telah selesai digambar dalam program Plaxis.

Namun sebelum memulai pemodelan, profil tanah yang telah didapatkan sebelum proses identifikasi parameter harus disederhanakan dahulu menjadi jenjang setiap 1m karena keterbatasan grid yang ada dalam program Plaxis. Tabel 3.2mengambarkan profil tanah yang telah disederhanakan menjadi interval $1 \mathrm{~m}$.

Tabel 3.2Penyederhanaan profil tanah

\begin{tabular}{|c|c|c|c|}
\hline $\mathrm{D}(\mathrm{m})$ & Point 1 & Point 4 & Point 5 \\
\hline 0 & Sensitive fine grained & Organic materials & Organic materials \\
\hline 1 & Sensitive fine grained & Organic materials & Organic materials \\
\hline 2 & Sensitive fine grained & Organic materials & Sensitive fine grained \\
\hline 3 & Sensitive fine grained & Organic materials & Sensitive fine grained \\
\hline 4 & Sensitive fine grained & Organic materials & Sensitive fine grained \\
\hline 5 & Sand to silty sand & Clay & Sandy silt to clayey silt \\
\hline 6 & Sand to silty sand & Clay & Silty sand to sandy silt \\
\hline 7 & Sand & Sensitive fine grained & Silty sand to sandy silt \\
\hline 8 & Sand & Sensitive fine grained & Silty sand to sandy silt \\
\hline 9 & Sand & Sandy silt to clayey silt & Sand to silty sand \\
\hline 10 & Sand & Silty sand to sandy silt & Sand to silty sand \\
\hline 11 & Sand & Silty sand to sandy silt & Sand to silty sand \\
\hline 12 & Sand & Sand to silty sand & Sand to silty sand \\
\hline 13 & Sand & Sand to silty sand & Sand to silty sand \\
\hline 14 & Sand & Sand to silty sand & Sand to silty sand \\
\hline 15 & Sand & Sand to silty sand & Sand \\
\hline 16 & Sand & Sand to silty sand & Sand \\
\hline 17 & Sand & Sand to silty sand & Sand \\
\hline 18 & Sand & Sand & Sand \\
\hline 19 & Sand & Sand & Sand \\
\hline 20 & Sand & Sand & Sand \\
\hline 21 & Sand & Sand & Sand \\
\hline
\end{tabular}




\begin{tabular}{|c|c|c|c|}
\hline $\mathrm{D}(\mathrm{m})$ & Point 1 & Point 4 & Point 5 \\
\hline 22 & Sand & Sand & Sand \\
\hline 23 & Sand & Sand & Sand \\
\hline
\end{tabular}

\subsection{Analisis Faktor Keamanan}

Gambar 3.1menunjukkan angka faktor keamanan kritis bantaran sungai tanpa perkuatan apapun, tanah dengan menggunakan perkuatan sheet pile, dan tanah yang menggunakan sheet pile dan lapisan kontrol erosi. Berdasarkan hasil eksekusi program Plaxis untuk keenam potongan bantaran sungai Tanjung Selor tanpa adanya perkuatan, didapatkan nilai faktor keamanan paling rendah adalah 0.0513 yang berada pada potongan 0 . Sedangkan potongan yang mendekati stabil adalah potongan 1 dengan faktor keamanan sebesar 0.6073 .

Lalu untuk hasil eksekusi program Plaxis untuk keenam potongan bantaran sungai Jelarai dengan perkuatan sheet pile, didapatkan nilai faktor keamanan paling rendah adalah 1.502 yang berada pada potongan 6 . Sedangkan potongan yang terbesar adalah potongan 5 dengan faktor keamanan sebesar 1.573 .

Dan yang terakhir merupakan hasil eksekusi program Plaxis untuk keenam potongan bantaran sungai Jelarai dengan perkuatan sheet pile dan lapisan kontrol erosi, didapatkan nilai faktor keamanan paling rendah adalah 1.557 yang berada pada potongan 3. Sedangkan potongan yang terbesar adalah potongan 6 dengan faktor keamanan sebesar 1.774. Maka dapat disimpulkan bahwa penambahan lapisan kontrol erosi berupa grouted riprap menambah nilai faktor keamanan dibandingkan dengan penambahan perkuatan dengan sheet pile saja.

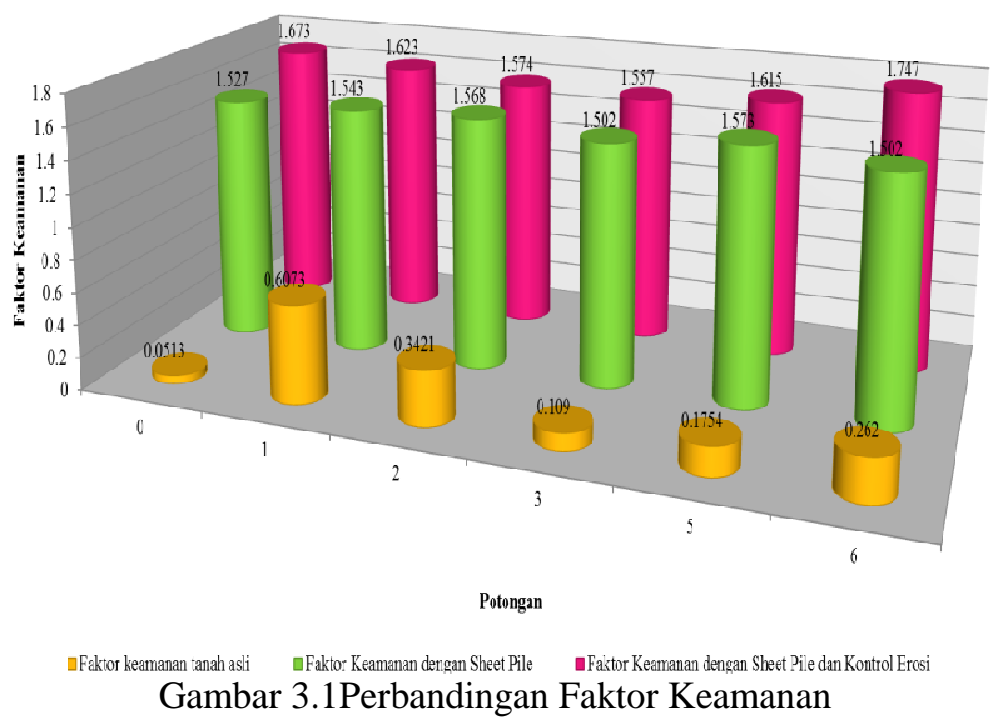

\subsection{Analisis Displacement}

\subsubsection{Analisis Displacement Tanah}

Gambar 3.2menunjukkan angka displacement bantaran sungai tanpa perkuatan apapun, tanah dengan menggunakan perkuatan sheet pile, dan tanah yang menggunakan sheet pile dan lapisan kontrol erosi. Berdasarkan hasil eksekusi program Plaxis untuk keenam potongan bantaran sungai Tanjung Selor tanpa adanya perkuatan, didapatkan nilai displacement paling tinggi adalah $18335 \mathrm{~mm}$ yang berada pada potongan 0 . Sedangkan potongan yang mendekati stabil adalah 
potongan 1 dengan faktor keamanan sebesar $1549 \mathrm{~mm}$. Maka dibutuhkan penambahan perkuatan sheet pile terutama pada potongan 0 yang memiliki displacement runtuh yang besar mencapai $18,35 \mathrm{~m}$.

Lalu untuk hasil eksekusi program Plaxis untuk keenam potongan bantaran sungai Jelarai dengan perkuatan sheet pile, didapatkan nilai displacement paling tinggi adalah $178,87 \mathrm{~mm}$ yang berada pada potongan 3. Sedangkan potongan yang memilikin displacement terkecil adalah potongan 6 dengan displacement sebesar 106,31 mm.

Dan yang terakhir merupakan hasil eksekusi program Plaxis untuk keenam potongan bantaran sungai Jelarai dengan perkuatan sheet pile dan lapisan kontrol erosi, didapatkan nilai displacement paling tinggi adalah $167,91 \mathrm{~mm}$ yang berada pada potongan 3 . Sedangkan potongan yang memilikin displacement terkecil adalah potongan 6 dengan displacement sebesar 93,66mm. Maka dapat disimpulkan bahwa penambahan lapisan kontrol erosi berupa grouted riprap mengurangi nilai displacement dibandingkan dengan penambahan perkuatan dengan sheet pile saja.

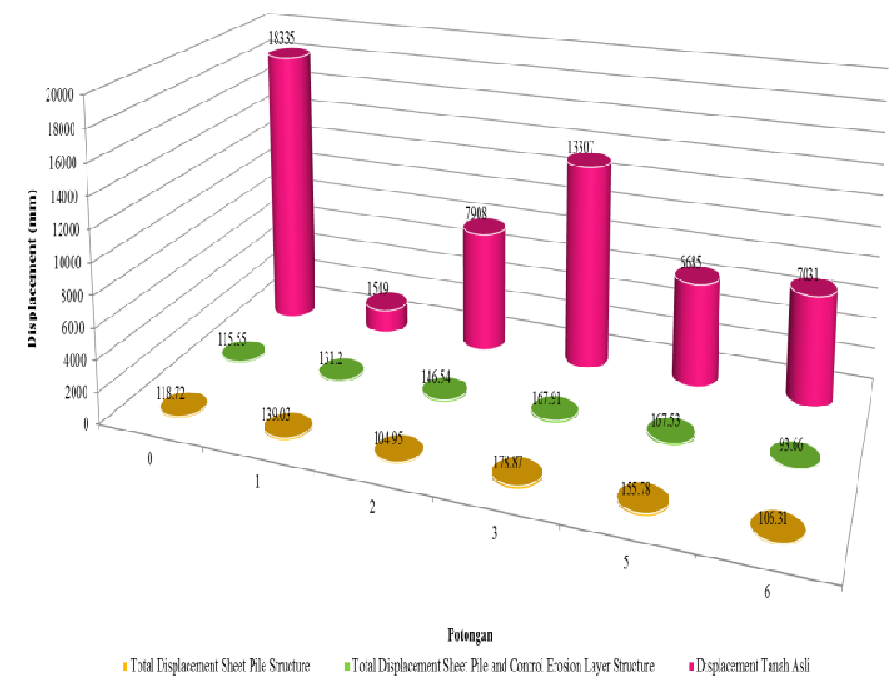

Gambar 3.2Perbandingan Displacement Tanah

\subsubsection{Analisis Displacement Sheet Pile}

Gambar 3.3menunjukkan angka lendutan sheet pile, dan sheet pile yang dilengkapi dengan lapisan kontrol erosi. Berdasarkan hasil eksekusi program Plaxis untuk keenam potongan bantaran sungai Jelarai dengan perkuatan sheet pile, didapatkan nilai lendutan paling tinggi adalah $186,04 \mathrm{~mm}$ yang berada pada potongan 3 . Sedangkan potongan yang memilikin lendutan terkecil adalah potongan 6 dengan lendutan sebesar $111,29 \mathrm{~mm}$.

Dan yang terakhir merupakan hasil eksekusi program Plaxis untuk keenam potongan bantaran sungai Jelarai dengan perkuatan sheet pile dan lapisan kontrol erosi, didapatkan nilai lendutan paling tinggi adalah $174,67 \mathrm{~mm}$ yang berada pada potongan 3 . Sedangkan potongan yang memilikin lendutan terkecil adalah potongan 6 dengan lendutan sebesar 100.04mm. Maka dapat disimpulkan bahwa penambahan lapisan kontrol erosi berupa grouted riprap mengurangi nilai lendutan struktur sheet pile. 


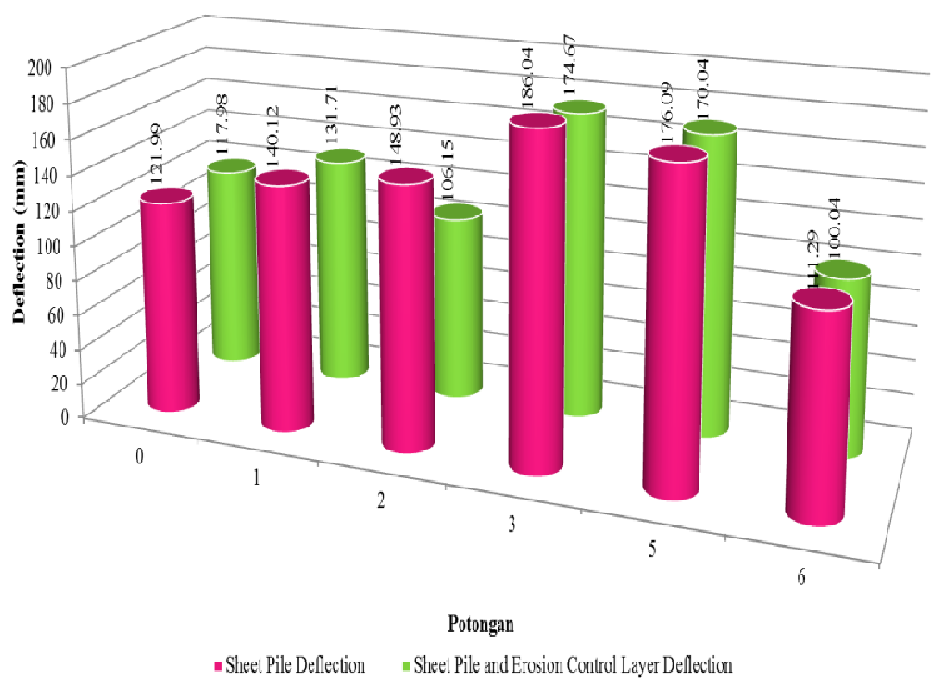

Gambar 3.3Perbandingan Displacement Sheet Pile

\subsubsection{Analisis Effective Stress}

Gambar 3.4menunjukkan angka tegangan rata-rata tanah bantaran sungai tanpa perkuatan apapun, tanah dengan menggunakan perkuatan sheet pile, dan tanah yang menggunakan sheet pile dan lapisan kontrol erosi. Berdasarkan hasil eksekusi program Plaxis untuk keenam potongan bantaran sungai Tanjung Selor tanpa adanya perkuatan, didapatkan nilai tegangan rata-rata tanah paling tinggi adalah $192,3 \mathrm{kNm} / \mathrm{m}$ yang berada pada potongan 0 . Sedangkan potongan yang memiliki angka tegangan rata-rata tanah paling kecil adalah potongan 5 dengan nilai sebesar $132,17 \mathrm{kNm} / \mathrm{m}$. Maka dibutuhkan penambahan perkuatan sheet pile terutama pada potongan 0 yang memiliki tegangan rata-rata tanah runtuh yang besar mencapai $18,35 \mathrm{~m}$.

Lalu untuk hasil eksekusi program Plaxis untuk keenam potongan bantaran sungai Jelarai dengan perkuatan sheet pile, didapatkan nilai tegangan rata-rata tanah paling tinggi $293,46 \mathrm{kNm} / \mathrm{m}$ yang berada pada potongan 3 . Sedangkan potongan yang memilikin tegangan rata-rata tanah terkecil adalah potongan 5 dengan tegangan rata-rata tanah sebesar $219,73 \mathrm{kNm} / \mathrm{m}$.

Dan yang terakhir merupakan hasil eksekusi program Plaxis untuk keenam potongan bantaran sungai Jelarai dengan perkuatan sheet pile dan lapisan kontrol erosi, didapatkan nilai tegangan ratarata tanah paling tinggi adalah $286,86 \mathrm{kNm} / \mathrm{m}$ yang berada pada potongan 3 . Sedangkan potongan yang memilikin tegangan rata-rata tanah terkecil adalah potongan 5 dengan tegangan rata-rata tanah sebesar $217,76 \mathrm{kNm} / \mathrm{m}$. Maka dapat disimpulkan bahwa penambahan lapisan kontrol erosi berupa grouted riprap mengurangi nilai tegangan rata-rata tanah dibandingkan dengan penambahan perkuatan dengan sheet pile saja. 


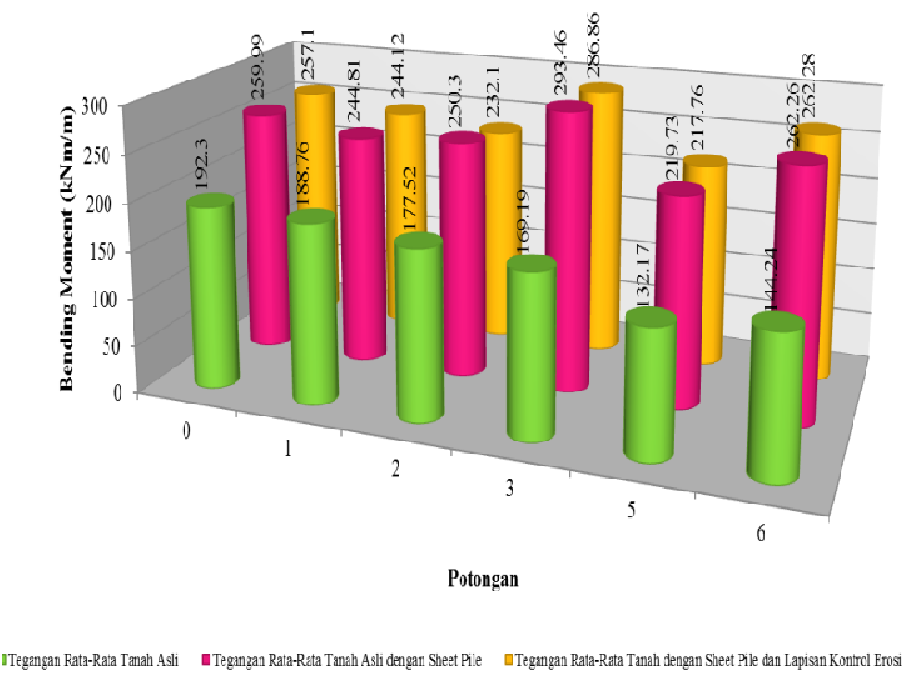

Gambar 3.4Perbandingan Tegangan Rata-Rata Tanah

\subsubsection{Analisis Bending Moment}

Gambar 3.5menunjukkan angka momen lentur sheet pile, dan sheet pile yang dilengkapi dengan lapisan kontrol erosi. Berdasarkan hasil eksekusi program Plaxis untuk keenam potongan bantaran sungai Jelarai dengan perkuatan sheet pile, didapatkan nilai momen lentur paling tinggi adalah $107,77 \mathrm{kN} / \mathrm{m} 2$ yang berada pada potongan 5 . Sedangkan potongan yang memilikin momen lentur terkecil adalah potongan 1 dengan momen lentur sebesar $31,3 \mathrm{kN} / \mathrm{m} 2$.

Dan yang terakhir merupakan hasil eksekusi program Plaxis untuk keenam potongan bantaran sungai Jelarai dengan perkuatan sheet pile dan lapisan kontrol erosi, didapatkan nilai momen lentur paling tinggi adalah $125,19 \mathrm{kN} / \mathrm{m} 2$ yang berada pada potongan 3 . Sedangkan potongan yang memilikin momen lentur terkecil adalah potongan 0 dengan momen lentur sebesar $34,64 \mathrm{kN} / \mathrm{m} 2$ Maka dapat disimpulkan bahwa penambahan lapisan kontrol erosi berupa grouted riprap mengurangi nilai momen lentur struktur sheet pile.

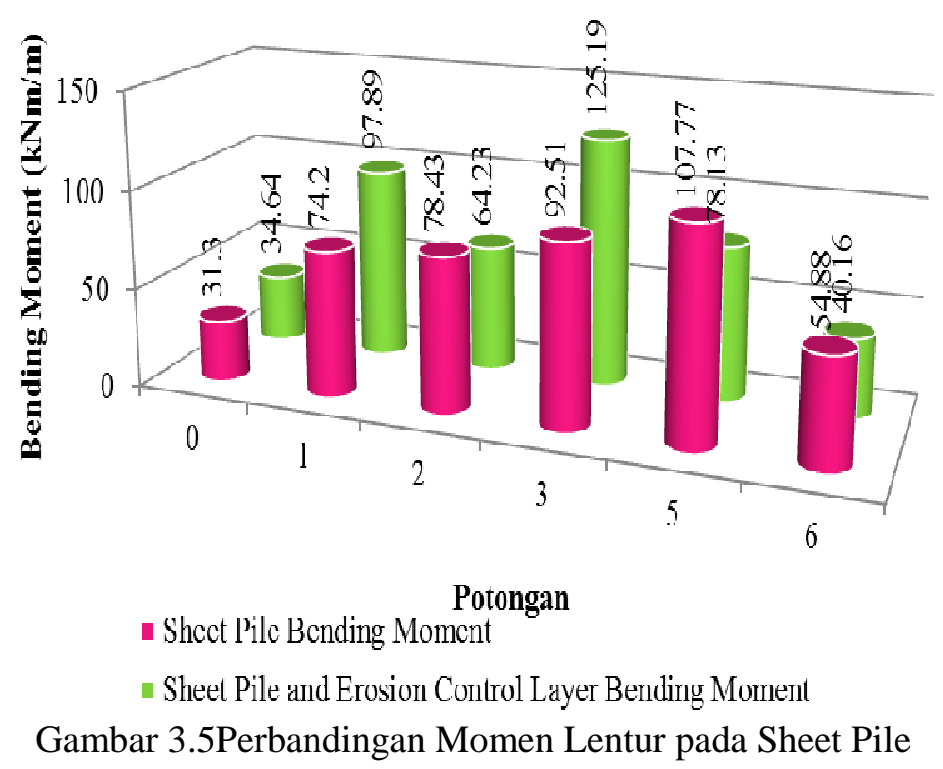




\section{PENUTUP}

\subsection{Kesimpulan}

1. Intrepetasi data CPT hasil tes sondir pada sungai Jelarai menyatakan bahwa jenis tanah yang dominan adalah tanah berpasir.

2. Tanah diberikan timbunan $2 \mathrm{H}: 1 \mathrm{~V}$ sebelum pemasangan sheet pile karena jenis tanah granular yang mudah lepas.

3. Setelah pemasangan sheet pile diberikan lapisan kontrol erosi untuk memperlambat proses erosi arus sungai berupa grouted riprap dan penanaman tumbuhan diatasnya untuk menambah kekuatan dan keasrian sungai Jelarai.

4. Faktor keamanan kritis tanah asli paling rendah terdapat pada potongan 0 yaitu 0,0513 .

5. Setelah penambahan struktur kontrol erosi, faktor keamanan bantaran sungai naik menjadi 1,774 pada potongan 6.

6. Perkuatan sheet pile dan lapisan kontrol erosi mampu mengurangi displacement tanah yang signifikan, seperti pada potongan 0 yang memiliki displacement awal sebesar $18335 \mathrm{~mm}$ menjadi $118,72 \mathrm{~mm}$.

7. Sheet pile yang digunakan memiliki nilai lendutan terbesar pada potongan 5 yaitu $186,04 \mathrm{~mm}$ tanpa penambahan struktur lapisan kontrol erosi.

8. Tegangan rata-rata tanah yang paling besar terjadi pada potongan 3 yaitu $293,46 \mathrm{kNm} / \mathrm{m}$ tanpa penambahan struktur lapisan kontrol erosi.

9. dan yang terakhir, sheet pile mampu menahan momen lentur yang terjadi pada potongan 3 setelah pemasangan lapisan kontrol erosi yaitu sebesar $125,19 \mathrm{kN} / \mathrm{m} 2$.

\subsection{Saran}

Analisis dalam penelitian ini merupakan tahapan yang panjang dan kompleks, maka diperlukan beberapa perbaikan dan pendalaman analisis yang belum sempat terlaksana pada penelitian kali ini. Bebrapa hal tersebut yaitu:

1. Analisa intrepetasi data CPT harus dilakukan sesuai dengan penemuan terbaru yaitu dengan metode perhitungan masing-maisng parameter, bukan dengan perkiraan data tanah tipikal.

2. Perencanaan grouted riprap sebagai lapisan kontrol erosi harus dilaksanakan lebih detail sesuai dengan SNI untuk mendapatkan ketebalan yang sesuai dengan kondisi alam Indonesia.

3. Karena keterbatasan perangkat keras yang ada, program Plaxis hanya mampu menggambar geometri tanah dengan ketelitian $1 \mathrm{~m} /$ grid. Sedangkan ketelitian yang diharapkan mencapai $0.01 \mathrm{~m} /$ grid. Maka diperlukan perangkat keras yang lebih besar dari RAM $1 \mathrm{~Gb}$ untuk mendapatkan ketelitian $0.01 \mathrm{~m} /$ grid pada program Plaxis.

\section{UCAPAN TERIMAKASIH}

Terimakasih kepada Bapak Eko A.S yang telah memberikan data CPT dan ide, Bapak As'ad Munawir untuk bimbingan, dan segenap sahabat dan dosen yang turut memberikan sumbangan doa dan ide.

\section{DAFTAR KEPUSTAKAAN}

Al-Azzawi, A. (2013). A Study of the Behavior of Shell Footings using Finite Element Analysis. International Conference for Geotechnical Engineering and Transportation, 90-102.

Anbya, Y. Y. (2013). Pengaruh Variasi Jarak dan Kedalaman Pondasi Terhadap Daya Dukung Pondasi di Lereng pada Pemodelan Fisik Tanah Pasir Dr 74\%. Malang: Universitas Brawijaya.

B.H, F., \& Eslami, A. (2000). Soil Profile Interpreted from CPTu Data. Geotechnical Engineering Conference (pp. 1-18). Bangkok: Asian Institute of Technology. 
Bailey, M. (2010, June 08). Cone Penetration Testing (CPT). Cone Penetration Testing (CPT). Savannah District, Savannah District, USA: U.S. Army Corps of Engineers.

Been, K., \& Quinonez, A. (2005). Interpretation of the CPT in engineering practice. Golder Ascociates, 1-19. Bowles, J. E. (1996). Foundation Analysis and Design. New York: McGraw Hill.

Branch, P. S. (2000). Riprap Design and Construction Guide. British Columbia: Canadian Catalogue.

C. S., \& M. G. (2009). Advances in Computational Limit State Analysis and Design. Department of Civil \& Structural Engineering, 10.

Cai, F., \& K. U. (2000). Numerical Analysis of the Stability of a Slope Reinforced with Piles. The Japanese Geotechnical Society, 12.

Cole, A. J. (2009). A Conprehensive Study of Footing on c- $\Phi$ Soil Slopes - Numerical and Physical Modelling. Queensland: University of Shouthern Queensland.

Das, B. M. (2007). Principles of Foundation Engineering. Stamford: Cengage Learning.

Eslami, A., \& Fellenius, B. (2004). CPT and CPTu Data for Soil Profile Interpretation:Review of Methods and a Proposed New Approach. Iranian Journal of Science and Technology, 69-86.

Fatnanta, F., \& Muhardi. (2009). Mekanika Tanah II. Jakarta: Universitas Gunadarma.

Fernandez, R. (2007). Soil Mechanics Analsis and Comparison to insitu Test Methods of Soil Found in Potrero Canyon. San Diego State University, 1-25.

Gunawan, I. R. (1990). Pengantar Teknik Pondasi. Yogyakarta: Kanisius.

Jacobs, P. (2004). Simplified Description of the Use and Design Methods for CPTs in Ground Engineering. Oxfordshire: Fugro Engineering Services Ltd.

Lunne, T., \& Yang, S. (2014). Session Report 2: CPT Interpretation. 3rd International Symposium on Cone Penetration Testing (pp. 145-153). Las Vegas: 3rd International Symposium on Cone Penetration Testing.

Nakazawa, K. (2000). Mekanika Tanah dan Teknik Pondasi. Jakarta: PT. Pradnya Paramita.

National Cooperative Highway Research Program. (2007). Cone Penetration Testing. Orlando: National Cooperative Highway Research Program.

Owuama, C. O. (2002). Semi-Empirical Method of Interpretation of CPT Data. JKAU : Eng. Sci, 31-43.

Purwana, Y. M., A. P., \& W. S. (2008). Metode Keseimbangan Batas vs Metode Elemen Hingga untu Analisis Pondasi Dangkal Menerus pada Tanah Kohesif. Media Teknik Sipil, 6.

Resources, I. D. (2006). How to Control Streambank Erosion. Iowa: U.S. Departement of Agriculture.

Schanaid, F., \& Houlsby, G. (1991). Measurement of the Properties of Sand by the Cone Pressuremeter Test. Departemen of Engineering Science University of Oxford, 1-35.

Setyabudi M.Sc., P. I. (2011). Pondasi Dangkal. Yogyakarta: Andi.

Sunitsakul, J., Sawatparnich, A., \& Apimeteetamrong, S. (2009). Basic soil properties from CPT in Bangkok clay for highway design. Departement of Highway, 1-8. 